\title{
PENGARUH VARIASI KUAT ARUS LISTRIK DAN WAKTU PENGADUKAN \\ PADA PROSES ELEKTROKOAGULASI UNTUK PENJERNIHAN AIR BAKUPDAM TIRTANADI IPA SUNGGAL
}

\author{
Sofia Novita \\ Surel: sofianovita@ymail.com
}

\begin{abstract}
Abstrak
Sampel diambil dari bak sedimentasi PDAM Tirtanadi IPA Sunggal yang biasanya dijernihkan dengan menggunakan tawas. Penelitian ini dilakukan dengan kapasitas laboratorium dan dilakukan dengan menggunakan logam aluminium sebagai elektroda. Penelitian ini dilakukan dengan memvariasikan arus dan pengadukan pada saat elektrokoagulasi berlangsung dan setelah elektrokoagulasi selesai dengan waktu tiap pengadukan selama 3 menit. Waktu yang dibutuhkan selama proses elektrokoagulasi berlangsung yaitu selama 45 menit, dan arus yang digunakan sebesar 3 ampere. Untuk memperluas daerah penyebaran ion-ion $A+$ sehingga pengikatan koloid dalam air dapat dimaksimalkan, pengadukan dilakukan dengan dua tahap yaitu pengadukan yang dilakukan pada saat elektrokoagulasi berlangsung dengan kecepatan $150 \mathrm{rpm}$ dan pengadukan yang dilakukan setelah elektrokoagulasi selesai dilakukan dengan kecepatan pengadukan yang digunakan yaitu $50 \mathrm{rpm}$. Dari hasil uji menunjukkan bahwa air hasil penjernihan dengan metode elektrokoagulasi yang divariasikan dengan pengadukan mengalami penurunan warna hingga $100 \%$ dan penurunan kekeruhan hingga $95.78 \%$.
\end{abstract}

Kata kunci: Elektrokoagulasi, Pengadukan, Elektroda Aluminium, dan Air Baku

\begin{abstract}
Sample was taken in the raw water tank of PDAM Tirtanadi IPA Sunggal that usual be purificated by alum. The research is conducted in laboratory capacity and using Aluminium as electrodes (anode and cathode) which has a conductivity is $3,8 \times 10^{7} \Omega^{-1} \cdot \mathrm{m}^{-1}$. This electrocoagulation research is done with combine electric current and mixing when the electrocoagulation is performing and after electrocoagulation has been done for 3 minutes in each mixing. The time needed for the process of purification is 45 minutes and electric current as 3 ampere. To make the spreading of $A^{+}$ion's become more extensive, the mixing do with two parts. They are the mixing when electrocoagulation is performing that velocity is $150 \mathrm{rpm}$ and the mixing when electrocoagulation has been done that velocity is $50 \mathrm{rpm}$. From the results that has been tested show that water as result for process of purification of water by electrocoagulation process that variate with mixing has decreasing of color until 100\% and decreasing of turbidity until $95.78 \%$
\end{abstract}

Keywords: Electrocoagulation, Mixing, Electrode Al, and Basic Water 


\section{PENDAHULUAN}

Air merupakan suatu bahan pokok yang sangat diperlukan oleh setiap mahluk hidup yang ada di bumi. Keberadaan sumber air bersih pada suatu daerah sangat mempengaruhi kehidupan mahluk hidup. Jika terdapat banyak sumber air bersih pada suatu daerah dapat dipastikan akan banyak orang yang menempati daerah tersebut. Namun, yang menjadi permasalahan pada lingkungan masyarakat pada saat ini yaitu terdapat suatu daerah dengan kepadatan masyarakat yang tinggi namun tidak memiliki sumber air bersih yang mencukupi untuk kebutuhan mereka.

Perusahaan Daerah Air Minum (PDAM) merupakan suatu badan usaha yang melayani masyarakat dalam penyediaan air minum. Dalam sistem produksinya, PDAM menggunakan sungai sebagai sumber penyedia air baku yang akan diolah dan kemudian didistribusikan ke seluruh masyarakat yang menjadi pelanggannya. Keberhasilan dari air olahan yang dihasilkan dapat dilihat dari tingkat kekeruhan, keasaman, maupun kandungan kontaminan-kontaminan lainnya yang membahayakan bagi manusia.

Pada kenyataannya air yang dihasilkan dari Perusahaan Daerah Minum (PDAM) yang telah dikonsumsi oleh masyarakat selama ini, masih menemukan beberapa masalah, yaitu jika air tersebut diendapkan atau didiamkan untuk beberapa saat, maka akan terbentuk endapan yang terkadang menghasilkan aroma yang kurang sedap. Bau dari air tersebut terkadang seperti berbau bahan kimia yaitu bau yang berasal dari Clorin atau yang dikenal masyarakat sebagai kaporit. Dan keadaan ini membuat masyarakat kurang puas akan air yang mereka dapatkan walaupun mau tidak mau mereka tetap menggunakan air tersebut.

Hal inilah yang mendorong penulis untuk melakukan penelitian yang bertujuan untuk menjernihkan air baku yang digunakan Perusahaan Daerah Air Minum dalam sistem produksinya. Ada beberapa metode yang dilakukan untuk penjernihan air seperti metode oksidasi, adsorbsi, flokulasi, maupun koagulasi.

Elektrokoagulasi adalah proses penggumpalan dan pengendapan partikelpartikel halus yang terdapat dalam air dengan menggunakan energi listrik. Adapun prinsip kerja dari sistem ini adalah dengan menggunakan dua buah lempeng elektroda yang dimasukkan kedalam bejana yang telah diisi dengan air yang akan dijernihkan. Selanjutnya kedua elektroda dialiri arus listrik searah sehingga terjadilah proses elektrokimia yang menyebabkan kation bergerak menuju katoda dan anion bergerak menuju anoda. Dan pada akhirnya akan terbentuk suatu flokulan yang akan mengikat kontaminan maupun partikel-partikel dari air baku tersebut. Penelitian tentang penjernihan air dengan sistem elektrokoagulasi ini sebenarnya sudah banyak dilakukan, dengan cara menggunakan elektroda berupa aluminium. Adapun hasil dari penelitian tersebut cukup bagus dalam menghasilkan air dengan kekeruhan rendah atau dapat dikatakan hampir jernih. 
Proses elektrokoagulasi yang banyak dilakukan adalah dengan mevariasikan nilai tegangan, sedangkan dengan memvariasikan arus listrik belum banyak dilakukan. Pada tugas akhir ini akan dilakukan proses penjernihan air dengan menggunakan proses elektrokoagulasi yang dikombinasikan dengan pengadukan sebagai proses lanjutan.Adapun pada proses elektrokoagulasi akan divariasikan arus listrik yang akan digunakan dan jumlah putaran tiap menit pada pengadukan yang dilakukan pada saat proses elektrokoagulasi berlangsung dan setelah proses elektrokoagulasi selesai dilakukan, sehingga dapat diteliti seberapa jauh pengaruh proses elektrokoagulasi yang diberikan pengadukan pada saat proses elektrokoagulasi berlangsung dan setelah proses elektrokoagulasi selesai dilakukan untuk menjernihkan air baku PDAM Tirtanadi IPA Sunggal.

\section{Proses Elektrokoagulasi}

Elektrokoagulasi dikenal juga sebagai elektrolisis gelombang pendek. Elektrokoagulasi merupakan suatu proses yang melewatkan arus listrik ke dalam air. Itu dapat digunakan menjadi sebuah uji nyata dengan proses yang sangat efektif untuk pemindahan bahan pengkontaminasi yang terdapat dalam air. Proses ini dapat mengurangi lebih dari 99\% kation logam berat. Pada dasarnya sebuah elektroda logam akan teroksidasi dari logam M menjadi kation $\left(M^{n}\right)$. Selanjutnya air akan menjadi gas hydrogen dan juga ion hidroksil $(\mathrm{OH})$.

Adapun prinsip kerja dari sistem ini adalah dengan menggunakan dua buah lempeng elektroda yang dimasukkan kedalam bejana yang telah diisi dengan air yang akan dijernihkan. Selanjutnya kedua elektroda dialiri arus listrik searah sehingga terjadilah proses elektrokimia yang menyebabkan kation bergerak menuju katoda dan anion bergerak menuju anoda. Dan pada akhirnya akan terbentuk suatu flokulan yang akan mengikat kontaminan maupun partikelpartikel dari air baku tersebut.

Interaksi-interaksi yang terjadi dalam larutan yaitu:

Migrasi menuju muatan elektroda yang berlawanan (elektroporesis) dan netralisasi muatan.

Kation ataupun ion hidroksil membentuk sebuah endapan dengan pengotor.

Interaksi kation logam dengan $\mathrm{OH}$ membentuk sebuah hidroksida dengan sifat adsorbsi yang tinggi selanjutnya berikatan dengan polutan (bridge coagulation). Senyawa hidroksida yang terbentuk membentuk gumpalan (flok) yang lebih besar.

Gas hydrogen membantu flotasi dengan membawa pollutan kelapisan bulk flok di permukaan cairan, (Holt P,2006). Mekanisme yang mungkin terjadi pada saat proses elektrokoagulasi berlangsung yaitu arus dialirkan melalui suatu elektroda logam, yang mengoksidasi logam (M) menjadi kationnya. Secara simultan, air tereduksi menjadi gas hydrogen dan ion hidroksil (OH-). Dengan demikian elektrokoagulasi memasukkan kation logam in situ, secara elektrokimia, dengan menggunakan anoda yang dikorbankan (biasanya aluminium atau besi). Kation terhidrolisis di dalam air yang membentuk hidroksida dengan spesies- 
spesies utama yang ditentukan oleh $\mathrm{pH}$ larutan. Kation bermuatan tinggi mendestabilisasi setiap partikel koloid dengan pembentukan komplek polihidrosida polivalen. Komplek-komplek ini memiliki sifatsifat penyerapan yang tinggi, yang membentuk agregat dengan polutan. Evolusi gas hidrogen membantu dalam percampuran dan karenanya membantu flokulasi. Begitu flok dihasilkan, gas elektrolitik menimbulkan efek pengapungan yang memindahkan polutan ke lapisan flok-foam pada permukaan cairan.

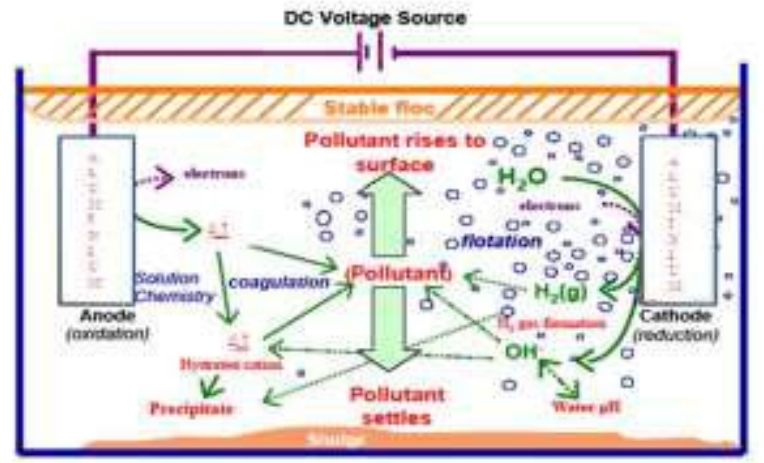

Gambar Mekanisme elektrokoagulasi (Holt, P, 2006)

\section{Kelebihan Elektrokoagulasi}

Elektrokoagulasi memerlukan peralatan sederhana dan mudah untuk dioperasikan.

Elektrokoagulasi lebih cepat mereduksi kandungan koloid/partikel yang paling kecil, hal ini disebabkan pengaplikasian listrik kedalam air akan mempercepat pergerakan mereka didalam air dengan demikian akan memudahkan proses.

Tidak diperlukan pengaturan $\mathrm{pH}$.

Tanpa menggunakan bahan kimia tambahan.

Dapat memindahkan partikel-partikel koloid yang lebih kecil

\section{Kelemahan Elektrokoagulasi}

Adapun kekurangan dari proses elektrokoagulasi ini adalah:

Tidak dapat digunakan untuk mengolah cairan yang mempunyai sifat elektrolit cukup tinggi dikarenakan akan terjadi hubungan singkat antar elektroda.

Besarnya reduksi logam berat dalam cairan dipengaruhi oleh besar kecilnya arus voltase listrik searah pada elektroda, luas sempitnya bidang kontak elektroda dan jarak antar elektroda.

Elektrodanya dapat terlarut sehingga dapat mengakibatkan terjadinya oksidasi. Penggunaan listrik yang mungkin mahal.

\section{METODE PENELITIAN}

Penjernihan air baku PDAM Tirtanadi Instalasi Pengolahan Air Sunggal dilakukan dalam skala laboratorium dengan menggunakan beaker glass. Untuk 
mendapatkan hasil yang maksimal, maka peneliti melakukan penjernihan air dengan metode elektrokoagulasi yang dikombinasikan dengan pengadukan sebagai proses lanjutan. Adapun pada proses elektrokoagulasi dilakukan dengan memvariasikan arus, dan diberikakan pengadukan pada saat proses elektrokoagulasi berlangsung dan setelah proses elektrokoaglasi selesai dilakukan. Tahap awal untuk mengetahui arus yang optimum, maka peneliti menggunakan rangkaian PSA yang dilengkapi dengan komponen elektronika sehingga arus dapat divariasikan. Sedangkan untuk parameter jumlah putaran per menit (rpm) maka penulis menggunakan alat jar test dan magnetic stirrer.

Sebelum melakukan percobaan, sampel air baku PDAM Tirtanadi IPA Sunggal terlebih dahulu dianalisis parameter-parameternya, yaitu: pH, Warna, Kekeruhan, Suhu, DHL, dan kadar logam Aluminium.

\section{Penjernihan Air dengan Metode Elektrokoagulasi Pada Air Baku PDAMTirtanadi IPA Sunggal}

Pengaturan alat sesuai dengan rancangan percobaan

Dimasukkan air baku PDAM Tirtanadi IPA Sunggal ke dalam beaker glass sebanyak $500 \mathrm{ml}$

Dimasukkan sepasang elektroda ( 1 Katoda dan 1 Anoda) ke dalam beaker glass

Diatur jarak antar elektroda sejauh 2,5 cm

Elektroda dialiri arus listrik $350 \mathrm{~mA}$ dengan tegangan 12 Volt selama 15 menit

Diuji nilai turbidity (kekeruhan), $\mathrm{pH}$, Konduktivitas, dan temperatur pada setiap waktu kontak

Diulangi langkah 1 hingga langkah 5 dengan waktu kontak 30 menit, 45 menit dan 60 menit

Penjernihan Air Baku PDAM Tirtanadi IPA Sunggal dengan Menggunakan Variasi Arus pada Metode Elektrokoagulasi

Pengaturan alat sesuai dengan rancangan percobaan.

Dimasukkan air baku PDAM Tirtanadi IPA Sunggal ke dalam beaker glass sebanyak $500 \mathrm{ml}$

Dimasukkan sepasang ( 1 Katoda dan 1 Anoda) elektroda ke dalam beaker glass

Diatur jarak antar elektroda sejauh 2,5 cm

Elektroda dialiri arus listrik $350 \mathrm{~mA}$ dengan tegangan 12 Volt dengan waktu kontak optimum pada percobaan 3.4.1

Diuji nilai turbidity (kekeruhan), $\mathrm{pH}$, Konduktivitas, dan temperatur pada setiap nilai arus yang digunakan

Diulangi langkah 4 dan 5 dengan menggunakan sumber arus $500 \mathrm{~mA}, 1 \mathrm{~A}, 2$ A dan 3 A

Penjernihan Air Baku PDAM Tirtanadi IPA Sunggal dengan Menggunakan Variasi Waktu pada saat Pengadukan 
Dimasukkan air baku PDAM Tirtanadi IPA Sunggal ke dalam beaker glass sebanyak $500 \mathrm{ml}$

Diaduk air sampel pada beaker glass dengan jumlah putaran $50 \mathrm{rpm}$ selama 1 menit

Diuji nilai turbidity (kekeruhan), $\mathrm{pH}$, Konduktivitas, dan temperatur pada setiap waktu kontak

Diulangi langkah 1 dan 2 dengan menggunakan waktu kontak selama 3 menit, 5 menit, dan 7 menit.

Penjernihan Air Baku PDAM Tirtanadi IPA Sunggal dengan Menggunakan Variasi Putaran pada Pengadukan

Dimasukkan air baku PDAM Tirtanadi IPA Sunggal ke dalam beaker glass sebanyak $500 \mathrm{ml}$

Diaduk air sampel pada beaker glass dengan jumlah putaran $50 \mathrm{rpm}$ dengan waktu kontak optimum

Diuji nilai turbidity (kekeruhan), $\mathrm{pH}$, Konduktivitas, dan temperatur pada setiap jumlah putaran yang digunakan

Diulangi langkah 1 dan 2 dengan menggunakan jumlah putaran $100 \mathrm{rpm}$ dan $150 \mathrm{rpm}$

Penjernihan Air Baku PDAM Tirtanadi IPA Sunggal dengan Metode Elektrokoagulasi yang Dikombinasikan dengan Pengadukan Ketika Proses Elektrokoagulasi Berlangsung

Pengaturan alat sesuai dengan rancangan percobaan.

Dimasukkan air baku PDAM Tirtanadi IPA Sunggal ke dalam beaker glass sebanyak $500 \mathrm{ml}$

Dimasukkan sepasang elektroda ( 1 Katoda dan 1 Anoda) ke dalam beaker glass

Diatur jarak antar elektroda sejauh $2,5 \mathrm{~cm}$

5. Elektroda dialiri tegangan 12 Volt dengan arus listrik optimum pada percobaan kedua dan dengan waktu kontak optimum pada percobaan pertama Pada saat waktu kontak berlangsung, air diaduk dengan jumlah putaran 50 rpm dengan waktu kontak optimum pada percobaan ketiga

Dimatikan sumber arus

Diuji nilai turbidity (kekeruhan), $\mathrm{pH}$, Konduktivitas, dan temperatur pada setiap jumlah putaran yang digunakan

Diulangi langkah 1 hingga 7 dengan menggunakan jumlah putaran $100 \mathrm{rpm}$ dan $150 \mathrm{rpm}$

\section{Penjernihan Air Baku PDAM Tirtanadi IPA Sunggal dengan Metode}

\section{Elektrokoagulasi dan Pengadukan}

Pengaturan alat sesuai dengan rancangan percobaan.

Dimasukkan air baku PDAM Tirtanadi IPA Sunggal ke dalam beaker glass sebanyak $500 \mathrm{ml}$ 
Dimasukkan sepasang elektroda (1 Katoda dan 1 Anoda) ke dalam beaker glass

Diatur jarak antar elektroda sejauh 2,5 cm

5. Elektroda dialiri tegangan 12 Volt dengan arus listrik optimum pada percobaan kedua dan dengan waktu kontak optimum pada percobaan pertama Pada saat waktu kontak berlangsung, air diaduk dengan jumlah putaran optimum berdasarkan percobaan kelima dengan waktu kontak optimum pada percobaan ketiga

Dimatikan sumber arus

Diaduk kembali air dengan jumlah putaran optimum pada percobaan 3.4.4 dengan waktu kontak optimum pada percobaan 3.4.3

Diuji nilai turbidity (kekeruhan), $\mathrm{pH}$, Konduktivitas, dan temperatur pada setiap jumlah putaran yang digunakan dan kadar Logam Aluminium

\section{HASIL PENELITIAN DAN PEMBAHASAN}

\section{Hasil PenelitianPenjernihan Air Baku melalui Metode Elektrokoagulasi dengan Memvariasikan Arus}

Pada tahap pertama dilakukan percobaan dengan menggunakan dua variabel, yaitu waktu kontak dan kuat arus. Waktu kontak yang digunakan divariasikan menjadi empat variasi, yaitu selama 15 menit, 30 menit, 45 menit dan 60 menit. Sedangkan untuk arus listrik yang digunakan juga menggunakan lima variasi, yaitu $350 \mathrm{~mA}, 500 \mathrm{~mA}, 1$ A, 2 A dan 3 A. Pada percobaan ini sumber yang digunakan yaitu menggunakan trafo yang dirangkai sedemikian rupa sehingga membentuk suatu rangkaian PSA.

Pengaruh kuat arus terhadap penjernihan air baku PDAM Tirtanadi Sunggal dengan proses elektrokoagulasi

\begin{tabular}{|l|l|l|l|l|}
\hline No & $\begin{array}{l}\text { Arus } \\
(\mathrm{A})\end{array}$ & $\begin{array}{l}\text { Waktu } \\
\text { (menit) }\end{array}$ & $\begin{array}{l}\text { Kekeruhan } \\
\text { (NTU) }\end{array}$ & $\begin{array}{l}\text { Penurunan } \\
\text { Kekeruhan } \\
(\%)\end{array}$ \\
\hline \hline 1 & 0.35 & 15 & 35.58 & 44.4 \\
\hline 2 & 0.5 & 15 & 33.72 & 47.3 \\
\hline 3 & 1 & 15 & 32.064 & 49.9 \\
\hline 4 & 2 & 15 & 28.88 & 54.86 \\
\hline 5 & 3 & 15 & 24.24 & 62.11 \\
\hline
\end{tabular}

Pembentukan ion $\mathrm{Al}^{3+}$ sebagai koagulan dapat terjadi karena adanya reaksi yang terjadi pada anoda dan katoda sebagai pasangan elektroda selama proses elektrokoagulasi. Pelepasan ion $\mathrm{Al}^{3+}$ yang berasal dari elektroda sangatlah dipengaruhi oleh besarnya arus yang mengalir pada elektroda. Semakin besar arus yang mengalir pada elektroda maka akan semakin banyak pula ion $\mathrm{Al}^{3+}$ yang dilepaskan dari anoda sebagai agen koagulan. Sehingga pengikatan polutan 
pengikat air menjadi semakin banyak. Dari tabel di atas dapat terlihat jelas bahwasannya penurunan kekeruhan semakin meningkat dengan meningkatnya kuat arus yang digunakan. Sehingga pada arus optimum yang digunakan dapat menghasilkan air dengan nilai kekeruhan yang cukup rendah. Sama halnya dengan kuat arus yang digunakan, waktu kontak juga mempengaruhi beberapa parameter fisik pada air, terutama pada nilai kekeruhan. Dari percobaan yang dilakukan maka didapatkan beberapa data pada beberapa parameter fisik pada air hasil penjernihan dengan menggunakan proses elektrokoagulasi dengan beberapa waktu kontak.

\section{Pengaruh waktu kontak terhadap penjernihan air baku PDAM Tirtanadi Sunggal dengan proses elektrokoagulasi}

\begin{tabular}{|l|l|l|l|l|}
\hline No & $\begin{array}{l}\text { Waktu } \\
\text { (menit) }\end{array}$ & $\begin{array}{l}\text { DHL } \\
\text { (. -) }\end{array}$ & $\begin{array}{l}\text { Kekeruhan } \\
\text { (NTU) }\end{array}$ & $\begin{array}{l}\text { Penurunan } \\
\text { Kekeruhan } \\
(\%)\end{array}$ \\
\hline \hline 1 & 15 & 53 & 24.24 & 62.11 \\
\hline 2 & 30 & 53 & 22.54 & 64.78 \\
\hline 3 & 45 & 54 & 11.64 & 81.8 \\
\hline 4 & 60 & 54 & 10.56 & 83.5 \\
\hline
\end{tabular}

Pada dasarnya, semakin lama waktu yang digunakan pada saat proses elektrokoagulasi maka akan memberikan kesempatan kepada anoda untuk semakin banyak melepaskan ion $\mathrm{Al}^{3+}$ yang akan mengikat polutan air. Dari data yang ditunjukkan pada tabel di atas penurunan kekeruhan semakin meningkat dengan meningkatnya waktu kontak yang digunakan.

Kesimpulan yang dapat diambil bahwa kuat arus dan waktu kontak berbanding lurus dengan penurunan kekeruhan air hasil penjernihan dengan proses elektrokoagulasi. Atau dengan kata lain, semakin besar kuat arus yang digunakan semakin tinggi penurunan kekeruhan air, begitu pula dengan waktu kontak. Semakin lama waktu kontak yang digunakan pada proses elektrokoagulasi maka akan semakin tinggi pula penurunan kekeruhan air hasil penjernihan dengan proses elektrokoagulasi.

Pada prinsip kerjanya, ion-ion alumunium inilah yang berperan aktif sebagai koagulan. Yaitu pihak yang sangat bertanggung jawab untuk mengikat partikel-partikel koloid yang terdapat dalam air. Setelah ion alumunium berikatan dengan partikel-partikel pengganggu tersebut, maka keduanya akan membentuk suatu flok. Semakin lama flok-flok tersebut akan bergabung dengan flok lainnya sehingga membentuk flok yang lebih besar.

Pada air hasil elektrokoagulasi, terdapat dua jenis flok yang terbentuk. Flok pertama adalah flok yang mengendap pada dasar wadah dan flok kedua adalah flok yang berada pada permukaan air hasil penjernihan. Adapun flok yang mengendap pada dasar wadah merupakan flok-flok yang berukuran besar 
sehingga pada saat air didiamkan maka flok tersebut akan bersedimentasi pada dasar wadah. Sedangkan flok yang terdapat pada permukaan air disebabkan karena adanya gas hydrogen yang dilepaskan dari katoda yang mengangkat flok yang masih melayang pada air menuju permukaan air. Adapun peristiwa ini dikenal dengan flotasi. Flotasi adalah peristiwa terangkatnya flok-flok yang terbentuk pada proses elektrokoagulasi oleh gas hydrogen yang dihasilkan katoda menuju permukaan air.

Keberadaan kedua jenis flok yang terbentuk merupakan salah satu kelebihan dari penjernihan air dengan proses elektrokoagulasi, karena dengan adanya flok yang terdapat pada permukaan air akan mempermudah proses pemisahan air hasil penjernihan dengan flok yang terbentuk.

Dari data yang terdapat pada tabel penurunan kekeruhan di atas, dapat dilihat bahwa waktu dan arus optimum yang digunakan yaitu sebesar 3 ampere dengan waktu kontak 60 menit dapat menghasilkan persentase penurunan kekeruhan hingga 83,5\%. Dan setelah dikalkulasikan dengan nilai kekeruhan awal pada air baku sebelum dilakukan penjernihan dengan metode elektrokoagulasi yang bernilai 64 NTU, maka setelah dilakukan penjernihan air baku yang dihasilkan memiliki nilai kekeruhan hanya pada nilai 10,56 NTU. Air baku yang digunakan memang memiliki tingkat kekeruhan yang sangat tinggi. Karena pengambilan sampel dilakukan pada saat sungai dalam keadaan banjir sehingga kekeruhan meningkat tajam. Nilai kekeruhan awal yang sangat tinggi ini menyebabkan walaupun persentase penurunan kekeruhan cukup tinggi, air yang dihasilkan belum memenuhi standar Peraturan Pemerintah No. 492 yang didalamnya menyatakan bahwa standar kekeruhan untuk air minum maksimal hanya berkisar pada nilai 5 NTU. Sedangkan air yang merupakan hasil proses elektrokoagulasi hanya mencapai 10,56 NTU, sangat jauh melebihi ambang batas persyaratan.

Hasil dari percobaan tahap pertama ini juga menegaskan teori bahwa, arus merupakan elektron yang mengalir, sehingga jika arus diperbesar, maka jumlah elektron yang mengalir dalam sel elektrolit (dari anoda ke katoda) juga akan semakin besar. Peningkatan jumlah elektron ini, juga meningkatkan jumlah $\mathrm{OH}^{-}$ dan gelembung gas $\mathrm{H}_{2}$ yang dihasilkan pada saat elektrokoagulasi berlangsung. Adapun gas hydrogen yang terbentuk bermanfaat untuk mengangkat flok-flok yang telah terbentuk kebagian permukaan air.

Pada percobaan elektrokoagulasi, plat elektroda yang digunakan selalu dihubungkan dengan sumber arus DC. Hal inilah yang menyebabkan pada air hasil pengolahan akan mengandung logam yang terlarut dimana jumlah logam tersebut akan sebanding dengan jumlah arus yang mengalir pada elektroda. Hal ini berhubungan dengan hukum Faraday yang mengatakan "Massa zat yang timbul pada elektroda karena elektrolisis berbanding lurus dengan jumlah listrik yang mengalir melalui larutan".Dalam percobaan ini, logam terlarut yang terdapat dalam air hasil penjernihan dengan metode elektrokoagulasi tidak dilakukan pada 
seluruh perubahan waktu kontak, namun hanya pada waktu yang optimum. Namun kandungan logam terlarut pada waktu kontak lainnya dapat dihitung dengan cara melihat perubahan massa elektroda yang digunakan selama proses elektrokoagulasi yang berlangsung. Sehingga dapat diperoleh berapa massa logam yang terlarut dalam air sebagai berikut.

Pengaruh waktu terhadap jumlah logam terlarut secara praktik dan teori pada proses penjernihan air

\begin{tabular}{|l|l|l|l|l|}
\hline NO & Waktu & Massa & Massa & Hasil \\
& $\begin{array}{l}\text { Kontak } \\
\text { (menit) }\end{array}$ & $\begin{array}{l}\text { Awal } \\
\text { Elektroda } \\
\text { (gram) }\end{array}$ & $\begin{array}{l}\text { Akhir } \\
\text { Elektroda } \\
\text { (gram) }\end{array}$ & $\begin{array}{l}\text { Perhitun } \\
\text { gan } \\
\text { (gram) }\end{array}$ \\
\hline 1 & 15 & 19.2615 & 19.26 & 0.00311 \\
\hline 2 & 30 & 19.6407 & 19.6368 & 0.00621 \\
\hline 3 & 45 & 19.6862 & 19.6808 & 0.00932 \\
\hline 4 & 60 & 19.6797 & 19.6693 & 0.01242 \\
\hline
\end{tabular}

Daya hantar listrik atau konduktivitas pada air merupakan bilangan yang menyatakan kemampuan larutan cair untuk menghantarkan arus listrik. Daya hantar listrik air tergantung dari konsentrasi ion dan suhu air, oleh karena itu kenaikan padatan terlarut akan mempengaruhi kenaikan daya hantar listrik. Biasanya makin tinggi daya hantar listrik dalam air, maka air akan terasa payau sampai asin.

Pada air hasil penjernihan dengan metode elektrokoagulasi terdapat kenaikan pada nilai daya hantar listrik. Namun pada beberapa keadaan air yang dihasilkan juga mengalami penurunan pada nilai daya hantar listriknya. Adapun penyebab meningkatnya nilai daya hantar listrik ini yaitu karena meningkatnya kandungan logam Al pada air. Sehingga terdapat banyak konduktor yang mampu menghantarkan listrik dengan baik. Sedangkan penyebab terjadinya penurunan daya hantar listrik pada air hasil penjernihan karena disebabkan beberapa faktor. Adapu faktor pertama yang menyebabkan penurunan daya hantar listrik yaitu karena pada saat pengukuran nilai daya hantar listrik masih terdapat flokulanflokulan yang merupakan gumpalan kotoran air yang merupakan bahan isolator sehingga menurunkan kemampuan air untuk menurunkan arus listrik. Adapun faktor lain yang menyebabkan penurunan daya hantar listrik yaitu karena pada saat pengukuran terdapat gelembung udara yang masuk ke dalam probe konduktivitimeter atau dapat dikatakan dengan kesalahan yang terdapat alat pengukuran.

Perubahan yang terjadi pada nilai daya hantar listrik air hasil elektrokoagulasi baik penurunan maupun peningkatan tidaklah menjadi suatu permasalahan, karena perubahan nilai yang terjadi masih menghasilkan nilai daya 
hantar lisrik yang masih di bawah standard air minum. Sehingga kualitas air masih tetap terjaga.

Pengaruh waktu kontak terhadap penjernihan air baku PDAM Tirtanadi Sunggal dengan proses elektrokoagulasi dengan pengadukan

\begin{tabular}{|l|l|l|l|l|}
\hline NO & $\begin{array}{l}\text { Waktu } \\
\text { (menit) }\end{array}$ & DHL & $\begin{array}{l}\text { Kekeruhan } \\
\left({ }^{-1}\right)\end{array}$ & $\begin{array}{l}\text { Penurunan } \\
\text { Kekeruhan } \\
(\%)\end{array}$ \\
\hline 1 & 15 & 53 & 20.47 & 68.01 \\
\hline 2 & 30 & 53 & 12.55 & 80.38 \\
\hline 3 & 45 & 54 & 7.64 & 88.06 \\
\hline 4 & 60 & 54 & 6 & 90.62 \\
\hline
\end{tabular}

Dari hasil percobaan dapat terlihat bahwasannya penurunan kekeruhan sudah mencapai $90 \%$ pada saat waktu kontak elektrokoagulasi dilakukan selama 60 menit, namun walaupun penurunan kekeruhan yang sangat tinggi belum menghasilkan air yang sesuai dengan standar air minum yang telah ditetapkan Permenkes Nomor 492/MENKES/PER/IV/2010 Tentang Persyaratan Kualitas Air Minum yang mensyaratkan air minum harus memiliki nilai kekeruhan maksimal 5 NTU. Gambar berikutakan menggambarkan hubungan antara waktu kontak elektrokoagulasi terhadap penurunan kekeruhan pada tiap-tiap jumlah putaran per menit. Dan untuk data penurunan kekeruhan pada tiap-tiap waktu kontak dan kecepatan pengadukan dapat dilihat pada gambar berikut.

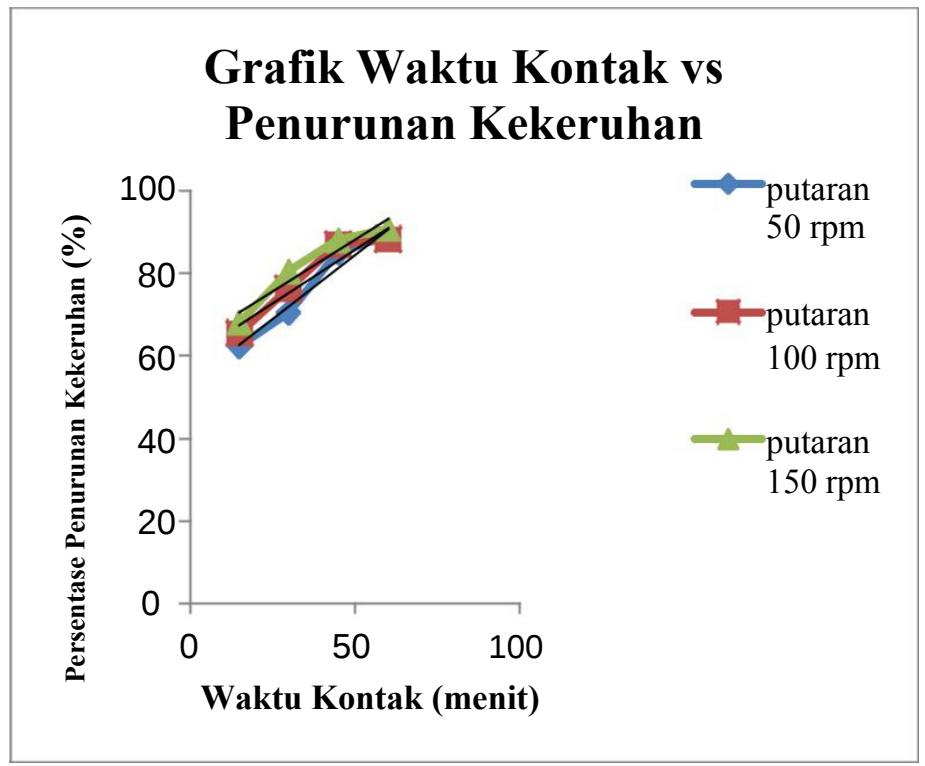

Gambar Waktu Kontak vs Penurunan Kekeruhan 


\section{Penjernihan Air Baku melalui Metode Elektrokoagulasi yang Dikombinasikan dengan Pengadukan}

Setelah dilakukan percobaan elektrokoagulasi yang diberikan pengadukan, didapatkan bahwa waktu kontak dan jumlah putaran yang digunakan adalah yang waktu kontak dan jumlah putaran yang paling optimum. Hal ini mengakibatkan persentase penurunan kekeruhan yang paling optimum pula. Namun berbeda dengan proses pengadukan yaitu metode penjernihan air hanya dengan melakukan putaran pada air, jumlah putaran yang digunakan adalah jumlah putaran yang paling kecil untuk menghasilkan persentase penurunan kekeruhan yang paling tinggi. Hal ini dikarenakan jumlah putaran yang tinggi akan menyebabkan pecahnya flok-flok yang sudah terbentuk, sehingga digunakan putaran yang lambat dan dalam waktu kontak yang tidak terlalu lama.

Dalam percobaan ini akan dikombinasikan antara elektrokoagulasi dengan pengadukan dan kemudian akan dilanjutkan kembali dengan pengadukan saja setelah waktu kontak elektrokoagulasi yang diberikan pengadukan selesai dilakukan. Sehingga terdapat dua metode yang dikombinasikan dalam percobaan ini. Adapun arus listrik yang digunakan untuk proses elektrokoagulasi adalah kuat arus yang paling optimum pada percobaan tahap pertama, sedangkan jumlah putaran yang digunakan pada saat elektrokoagulasi berlangsung juga merupakan jumlah putaran yang paling optimum. Dan untuk proses lanjutannya yaitu proses pengadukan akan digunakan jumlah putaran minimum dari percobaan pengadukan.

Adapun data yang dihasilkandari percobaan elektrokoagulasi yang diberikan pengadukan dan dilanjutkan kembali dengan pengadukan setelah waktu kontak selesai dilakukan.

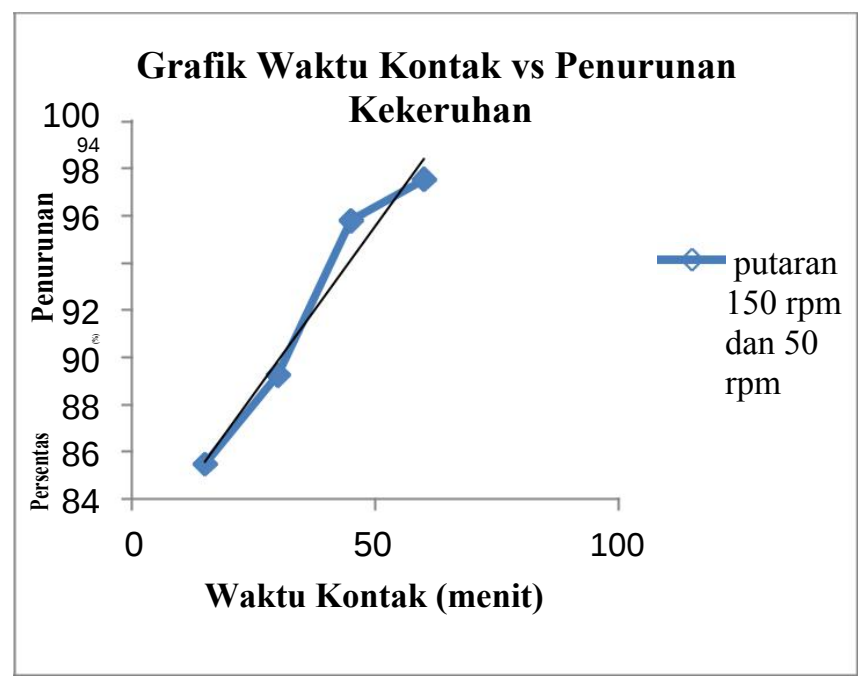

Gambar Waktu Kontak vs PenurunanKekeruhan

Dari grafik diatas, dapat terlihat bahwa penurunan kekeruhan semakin meningkat dengan semakin lamanya waktu kontak yang digunakan. Namun pada percobaan yang telah dilakukan dapat terlihat bahwa waktu kontak 45 menit dan 
60 menit hanya memiliki sedikit perbedaan, dan setelah dikalkulasikan dengan kekeruhan awal pada air baku, waktu kontak 45 menit sudah menghasilkan air yang telah memenuhi standar kekeruhan air minum yaitu di bawah 5 NTU, sehingga penggunaaan waktu kontak 45 menit sudah bisa menjadi waktu kontak yang efektif dalam proses elektrokoagulasi dengan variasi putaran. Walaupun waktu kontak 60 menit dapat menghasilkan air yang kekeruhan yang jauh dibawah standar, namun waktu kontak yang lama dikhawatirkan pada jumlah logam yang terlarut. Sehingga waktu kontak 60 menit tidak perlu untuk dilakukan.

Sebelum proses penjernihan air dengan menggunakan metode elektrokoagulasi dan pengadukan, air baku yang digunakan sebagai sampel dilakukan pengujian. Dan setelah proses penjernihan air baku akan diuji kembali. Adapun pengujian dilakukan untuk memeriksa beberapa parameter fisika dan kimia untuk air minum. Adapun pengukuran yang dilakukan untuk parameter fisik air minum yaitu kekeruhan, warna, temperatur, dan konduktivitas. Sedangkan pengukuran yang dilakukan untuk parameter kimia yaitu $\mathrm{pH}$, dan kandungan Aluminium yang terkandung dalam air. Pengukuran ini dilakukan untuk untuk mengetahui kelayakan air baku PDAM Tirtanadi IPA Sunggal yang memiliki warna coklat tua jika dikonsumsi sebagai air minum ataupun dikonsumsi untuk kebutuhan lainnya. Hasil uji dari parameter-parameter tersebut kemudian dibandingkan dengan standard yang digunakan untuk hasil pengujian pada

parameter-parameter air minum yaitu Permenkes Nomor 492/MENKES/PER/IV/2010 Tentang Persyaratan Kualitas Air Minum tanggal 10 April 2010. Pengujian air baku sebelum dan setelah proses penjernihan dilakukan sendiri oleh penulis di laboratorium Pengendalian Mutu Tirtanadi IPA Sunggal.

Dari data menunjukkan kandungan logam Al dari air hasil penjernihan bernilai $0.199 \mathrm{mg}$. Nilai ini jauh berbeda dengan nilai kandungan logam Al yang terdapat dalam air berdasarkan perhitungan massa elektroda sebelum dan sesudah proses penjernihan air yang bernilai 0.0054 gram. Sedangkan berdasarkan perhitungan menggunakan hukum Faraday kandungan logam Al yang terlarut dalam air bernilai 0.00932 gram. Penurunan jumlah kandungan logam Al yang terlarut dalam air terjadi karena sebelum dilakukan pengujian kandungan logam Al dengan menggunakan metode colorimetrik, air hasil penjernihan disaring terlebih dahulu dengan steril filter absorber yang dapat menurunkan kadar logam Al pada air hasil penjernihan dengan sangat baik. Hasil uji parameter-parameter seperti kekeruhan, warna, temperature, konduktivitas, dan $\mathrm{pH}$ dalam air menunjukkan bahwa air hasil penjernihan dengan metode elektrokoagulasi yang divariasikan dengan putaran memenuhi standar yang telah ditetapkan pada Permenkes Nomor 492/MENKES/PER/IV/2010 Tentang Persyaratan Kualitas Air Minum pada tanggal 10 April 2010, sehingga air tersebut layak untuk diminum jika ditinjau dari parameter-parameter fisika yang telah diuji. 


\section{DAFTAR RUJUKAN}

Bresnick, Stephen.2002. Intisari Fisika.Jakarta: Hipokrates.

Darmono. 2001. Lingkungan Hidup dan Pencemaran. Jakarta: UI-Press.

Departemen Kesehatan, Keputusan Menteri Kesehatan RI, Nomor 492/MENKES/PER/IV/2010, Tentang Persyaratan Kualitas Air Minum, (online) www.depkes.go.id.Diakses tanggal 20 Maret 2012.

Gabriel,J.F. 2001. Fisika Lingkungan. Jakarta: Hipokrates.

Hasanah,Moraida.2011. Efektivitas Elektroda Tembaga (Cu) Pada Proses Elektrokoagulasi Dalam Penjernihan Air Sungai Di Desa Air Hitam Kabupaten Labuhan Batu Utara. Skripsi. Medan: USU.

Holt, P.K., Barton, G.W., and Mitchell, C.A. 2004.Deciphering the Science Behind Electrocoagulation to Remove Suspended Clay Particles from Water, Water Science and Technology. Vol. 50 No. 12 pp 177-184, IWA Publishing.

Manda,Azzahra.2011.Pengertian Air dan Persyaratan Air. (online) http://Pengolahanairbaku.blogspot.com/2011/06/pengertian-air-dan-syaratsyarat-air. html, Diakses tanggal 29 februari 2012.

Purwaningsih, Indah. 2008. Pengolahan Limbah CaiBahan. 